\title{
Beyond Social Exchange Theory: A Theoretical Shift for Mentoring Relationships in the Federal Workplace
}

\section{Chad Majiros}

\begin{abstract}
This paper examines the principles of social exchange theory associated with the application of mentoring for knowledge transfer in the federal workplace. Specifically, federal workplace is intended to mean any U.S. government agency defined by bureaucratic processes in its operations. Max Weber's comparison of a bureaucracy to an iron cage is both classical and paramount to this discussion. Within the iron cage, Weber posed the further the organization perfects its operation, the more dehumanized the interaction between players (Farganis, 2011). Most important, due to the hierarchical structure and emphasis on career progression associated with the bureaucracy, mentoring relationships are often forged in a knowledge economy. Over time, mastery of skill is supported by a grasp of institutional history and organizational knowledge. Contemporary social work is aptly suited for investigating the barriers to, behavioral elements of, and best practices for fostering effective mentoring relationships in facilitating knowledge transfer between federal employees.
\end{abstract}

Keywords: Mentoring, mentoring relationships in the federal workplace, social exchange theory, mentoring dynamics, mentoring for knowledge transfer

A large turnover in the federal civilian workforce is expected over the next 10 years. The United States Office of Personnel Management (OPM) found that, by 2016, over $60 \%$ of employees will be eligible to retire (United States Office of Personnel Management, 2008a, p. 6). This mass exodus of retirees will have a direct impact on the working environment left behind at many federal agencies, perhaps compromising the ability of these agencies to fulfill their civic missions and provide services to the American public (United States General Accounting Office, 2001). As a result, government leaders must pay closer attention to the ramifications of lost knowledge (Davidson, 2010; DeLong, 2004; Godwin, 2009; Leuenberger \& Kluver, 2005/2006; Mason, 2010; Reeves, 2010; Talley, 2008). In response to losing contextual, historical, and operational knowledge, federal leaders have drafted The Federal Supervisor Training Act (2010). This legislation mandates mentoring practices for "transferring knowledge and advice in areas such as communication, critical thinking, responsibility, flexibility, motivating employees, teamwork, leadership, and professional development” (Federal Supervisor Training Act, 2010, p. 4). However, the proposed law fails to address how these mentoring programs are developed, evaluated, and implemented within the federal workplace.

This paper examines concepts and themes associated with the application of mentoring for knowledge transfer in the federal workplace. Specifically, federal workplace is intended to mean any U.S. government agency defined by bureaucratic processes in its operations. Max Weber's comparison of a bureaucracy to an iron cage is

Chad Majiros, MSW, is a Doctoral Student in the National Catholic School of Social Service at The Catholic University of America in Washington, DC.

Copyright (C) 2013 Advances in Social Work Vol. 14 No. 2 (Fall 2013), 531-543 
both classical and paramount to this discussion. Within the iron cage, Weber posed the further the organization perfects its operation, the more dehumanized the interaction between players (Farganis, 2011). Most important, due to the hierarchical structure reinforced by authority and routinization, government employees are encouraged to develop "technical superiority" (Farganis, 2011, p. 85) and through consistent daily practice develop a level of expertise (Farganis, 2011; Hughes, Sharrock, \& Martin, 2003; Reeves, 2010; Schroeder \& Swedberg, 2002). Ultimately, the wealth of experience and knowledge developed within the confines of the bureaucratic workplace afford the more seasoned government employees varying degrees of power and status (Darwin, 2000; Farganis, 2011; Fiol, O’Connor, \& Aguinis, 2001; Fouché \& Lunt, 2010; Reeves, 2010).

Social work has a unique contribution to make in this area. Examining the psychosocial aspects in mentoring relationships, specifically the necessity to promote mutual respect and trust, among employees is a novel idea that requires further study within the context of individual, group, and organizational culture. Social work is aptly suited for investigating the cultural (gender, generation, race), contextual (physical proximity, increased use of telecommuting, time), and structural (technology, hierarchical vs. horizontal) barriers to knowledge transfer within bureaucratic mentoring dyads (Cunningham, 1999; Heimann \& Pittenger, 1996; Matson \& Prusak, 2010).

\section{Mentoring Dynamics in the Workplace}

The premise behind successful implementation of workplace mentoring programs is based on two assumptions. First, can we assume employees have the competency or know-how to mentor and facilitate learning relationships? The inherent danger in assuming that every employee entrusted with supervisory authority can mentor others as a result of receiving some level of mandated training has the potential to exacerbate barriers already hindering workplace development. Second, can we truly assume employees want to share their knowledge? Especially when precedence suggests that in some bureaucratic organizations knowledge possession is more culturally valued than knowledge sharing.

The consensus throughout the literature is that the concept of mentoring first originated in Homer's Odyssey. Odysseus, king of Ithaca, fights in the Trojan War and entrusts the care of his household to Mentor, who serves as teacher and overseer of Odysseus' son, Telemachus. The word Mentor evolved to mean trusted advisor, friend, teacher, and wise person. Coincidentally, OPM defines mentoring as "a formal or informal relationship between two people - a senior mentor (usually outside the protégé's chain of supervision) and a junior protégé" (United States Officer of Personnel Management, 2008b, p. 2). The common elements in mentoring relationships include formal or informal dynamics, interpersonal skill, mutual respect, professional knowledge, reciprocity, time commitment, trust, and an understanding of adult learning principles (Cohen, 1999; Fouché \& Lunt, 2010; Higgins \& Kram, 2001; Shea, 2002; Zachary, 2000). For instance, Zachary (2000) emphasizes the importance of mentor preparation and reflection as a means to better facilitate a learning environment. Shea (2002) emphasizes the importance of mentor-like behavior in developing a mentoring relationship based on modeling behavior and teaching skills with varying levels of 
formality and duration. As well, Cohen (1999) emphasizes a mentor's ability to exercise flexibility within the relationship by assuming various roles in dimensions. Taking a more holistic approach, Higgins and Kram (2001) define mentoring using multiple relationships, based on diversity and strength of association, to articulate a developmental network perspective. Similar to Higgins and Kram, Fouché and Lunt (2010) published results after looking at tertiary relationships between social service providers in New Zealand. Their study tested the concept of nested mentoring relationships whereby relationship development was not restricted to the horizontal or vertical structures within organizations, but where participants established connections across agencies (Fouché \& Lunt, 2010).

Organizational culture and structure are critical factors in supporting the sharing of knowledge by whatever means. To illustrate, Donaldson, Ensher, and Grant-Vallone (2000) used a longitudinal framework to examine relationships between mentoring, organizational commitment, and citizenship behavior among a sample of nonprofessional protégés comprised of $70 \%$ women with an average age of 34 ( $n=408 ; 45 \%$ Latino American; 22\% European American; 15\% African American; 10\% Asian American; .05\% American Indian; 5.5\% other; 2\% did not report). The results support the hypothesis that diverse, non-professional protégés in high quality mentoring relationships report greater organizational commitment than protégés in low or moderate quality mentoring relationships (Donaldson et al., 2000).

Considering the context of the federal workplace and the potential ramifications for the Federal Supervisor Training Act, the concept of leader-member exchange will be essential to differentiating the roles of supervisor and mentor. Specifically, Wayne, Shore, and Liden (1997) suggest that some degree of leadership responsibility is inherent in the mentoring relationship. The application of leader-member exchange frames the mentoring relationship around transformational and transactional currency (Howell \& Hall-Merenda, 1999; Scandura \& Schriesheim, 1994; Sparrowe \& Liden, 1997). On one hand, the leader as mentor transforms the employee as mentee by means of change management and socialization. On the other hand, the leader provides emotional support and critical insider information based on the degree of followership received. To this point, Raabe and Beehr (2003) surveyed mentors and mentees in two companies while exploring the leader-member exchange framework further. The study deployed a questionnaire to 175 established mentor-mentee pairs. The response rates were $57 \%$ for mentors and $49 \%$ for mentees. Findings suggest "there was no evidence that the mentoring relationships were perceived in the same way by the two members of the mentor-mentee dyads" (Raabe \& Beehr, 2003, p. 284). Interestingly, this study also identifies a potential barrier in that "the lack of agreement about reciprocal relationships across vertical organizational boundaries" may reinforce a power differential (Raabe \& Beehr, p. 284). In this context, the elements and essence when defining the relationship, such as openness, respect, and trust, may be compromised by the duality of roles assumed by the supervisor as mentor. Further research in examining mentor and mentee perspectives within the leader-member framework is warranted (Ensher, Thomas, \& Murphy, 2001; Raabe \& Beehr, 2003). Conversely, Payne and Huffman (2005) surveyed 1,334 U.S. Army officers to measure levels of affective and continuance commitment as 
it related to mentoring effectiveness and organizational turnover. In this study, $81 \%$ of the participants report having at least one mentor with $68 \%$ of participants identifying supervisors as mentors and $85 \%$ report receiving career and job-related guidance from mentors (Payne \& Huffman, 2005). Findings suggest the relationship between mentoring and commitment is enhanced when supervisors serve as mentors. Interestingly, the authors suggest that future research examine the factors that influence a protégé's "attractiveness" (based on professional potential) implying that a mentor has a choice when engaging in a mentoring relationship (Payne \& Huffman, 2005, p. 166).

As leader-member elements impact the structural integrity for mentoring relationships, cultural barriers around gender appear just as concerning. Literature suggests that women of color have been marginalized when it comes to maximizing the benefits from participating in formal workplace mentoring programs. In fact, Katz (2013) brings to light the Equal Employment Opportunity Commission's report (2010) that found "unconscious biases, insufficient training and mentoring and outdated recruiting and hiring practices have stymied African Americans in federal government” (p. 1). With limited mentoring resources, female mentor-seeking behavior is polarized in label as either being "too dependent" (Sandberg, 2013, p. 66) or "assertive...sometimes misdirected" (Sandberg, 2013, p. 67). Although mentoring trends show that access to higher-level, managerial females has been improving (Combs, 2003), the existence of "perceived sexual intimacy" and "gender stereotypes" in some workplaces are obstacles to forming cross-gender mentoring relationships (O’Neill \& Blake-Beard, 2002, p. 52). Further exploration into how this group negotiates informal mentoring dynamics while creating workplace social capital is crucial (Gillies \& Edwards, 2006; Khosrovani \& Ward, 2011).

\section{Theoretical Underpinning for Mentoring Relationships}

Social exchange theory states that "interactions between persons are an exchange of goods, material and non-material” (Farganis, 2011, p. 233). Mentor's and mentee's participatory behaviors are based on the perceived benefits and costs in the relationship (Ensher et al., 2001). Exchange theory, as articulated by Homans and Blau, moved beyond the function of the environment and deployed the use of the self in creating expectations, obligations, and reciprocity with the other. Blau developed "macrostructural theory" (Homans, 1985, p. 396) to explain the importance of proximate position as the primary means of sanction within an organizational group. Interestingly, norms and values were viewed as mediating forces contributing to exchange principles when face-to-face interaction was not an option (Blau, 1955). For Blau, individual selfincentive governs social interaction in the workplace while norms and values serve as reinforcers in understanding exchange behavior (Blau \& Meyer, 1971).

Emerson was recognized for advancing the psychological framework of social exchange theory in his presentation of power and social influence (Ritzer, 2010). Emerson restricted the exchange label by defining it as either reciprocal exchange or negotiated exchange. He defines reciprocal exchange as the "sequential giving with unspecified terms and obligations", and negotiated exchange as the "agreement with specified terms and obligations” (Lawler \& Thye, 1999, p. 219). This concept led to 
Cook's work in identifying exchange networks. Cook contends that individuals make rational decisions to engage in workplace interactions with the goal of career and professional benefit (Cook \& Whitmeyer, 1992). Consequently, the interaction between self and other within a socially constructed environment results in the strengthening of approval and prestige as significant commodities or rewards.

In Farganis (2011), Coleman is credited with developing the concept of social capital. Conceptually, the meaning of self is altered as it assumes the identity of the collective. The collective norm becomes a powerful body of selves that acts to reward all in allegiance while minimizing the dichotomy of self and other. For Coleman, the choice to join the collective requires a significant level of trust by each individual member. Conformity in the here and now is defined by short-term social acceptance and long-term network benefits (Cook \& Whitmeyer, 1992; Farganis, 2011; Yair, 2007). Conversely, allegiance to the collective establishes a paradox in that individual choice is significantly influenced by forces of the environment or system (Lovett, 2006; Yair, 2007). Ultimately, interests, resources, and rewards are determined by "macro-level institutional factors" (Rambo, 1999, p. 319) and controlled by the individuals in power (Blau \& Meyer, 1971; Lovett, 2006).

\section{The Praxis of Social Exchange Theory}

The bureaucratic process lends itself to placing technical job expertise into the category of commodity. Formal mentoring is seen as a way to prepare an employee for career growth while developing internal human capital for filling job vacancies. This application of mentoring is reinforced by the vertical structure of a bureaucratic organization in which mostly explicit or codified knowledge is transferred. Knowledge, both explicit and tacit, is bartered, traded, and exchanged between employees making new employees especially vulnerable during any socialization processes. The disposition of a knowledge economy helps to reinforce status while establishing a social exchange for transferring knowledge. Once a specialist level of expertise is achieved, the agency becomes dependent on the hierarchical process where change is stifled and longevity becomes the primary means for security and self-preservation. Unfortunately, formal mentoring practices emphasize the inherent, didactic attributes in establishing the power relationship between mentor and mentee. For this reason, many scholars have framed workplace mentoring (formal) in social exchange theory. For instance, unlike explicit knowledge, tacit knowledge is the know-how gained from experiential learning and not easily taught or learned in a traditional training sense. Simply put, since tacit knowledge is hard to come by, it is elevated to a commodity and assigned value based on the premise that individual success (career progression, higher paying jobs, etc.) is related to higher levels of technical expertise and advanced operational knowledge (Farganis, 2011; Hughes et al., 2008; Reeves, 2010; Schroeder \& Swedberg, 2002). This dynamic reinforces dyadic power relationships, creates a foundation for leader-member exchange principles (Scandura \& Schriesheim, 1994; Sparrowe \& Liden, 1997), and establishes closed system boundaries inhibiting the sharing of knowledge. As tacit knowledge is rationed, reliance on explicit knowledge stifles "creativity and inventiveness" and may even lead to "corruption” (Martinez-Brawley \& Zorita, 2007, p. 537). Most important, it 
creates an ideology within the organizational culture that suggests knowledge is currency. From a bureaucratic standpoint and exchange perspective, the more seasoned mentor offers inside historical knowledge, career guidance, and technical tutelage to the inexperienced mentee who is limited in reciprocal resources. Tragically, the mentee's only recourse might be to offer loyalty, praise, and prestige in return.

At the core of the mentoring question is curiosity to better understand the motivation for participating in a relationship framed by competition and rite of passage. Social exchange theory in an organizational context, as presented by Homans and Blau, suggests that the mentoring relationship is defined by connection with temporal and emotional dimensions (Colley, 2002; Dutton \& Heaphy, 2003) whereby participants agree to rules of reciprocity (Cropanzano \& Mitchell, 2005) and a social ledger (Labianca \& Brass, 2006) in the workplace. The application of social exchange theory differs from Darwin's (2000) stance in radical humanism to account for the sharing of tacit knowledge where participants are seen more as peers instead of mentor and mentee (Darwin, 2000). Under the right structural circumstances, the social exchange is deepened by cultural and relational interactions where all parties benefit by contributing (Fouché \& Lunt, 2010; Liu, Liu, Kwan, \& Mao, 2009).

The capacity of social exchange theory to guide planned change in workplace mentoring relationships is related to organizational structure. The change effort is directed at the environment. The environment creates the organizational culture which reinforces the operational structure and assigns value to behavior. When considering how bureaucratic organizations are internally aligned to accommodate and facilitate knowledge transfer, the metaphor serves as a reminder in advocating for a restructuring of the workplace. The literature suggests that a decentralized, horizontal structure supports knowledge building and sharing, especially tacit-based knowledge (Hurley \& Green, 2005; Philipson, 2006; United States General Services Administration, 2009). In order for mentoring relationships to be an effective method for knowledge transfer, upper-management buy-in and support is required for the creation of a workplace culture that values sharing while considering the adverse impact of cultural, generational, and social barriers. Simply put, the organization must accommodate open and honest communication, encourage respectful and trusting relationships, and express value in effective mentoring relationships (Lam \& Lambermont-Ford, 2010; Levy, Hadar, Greenspan, \& Hadar, 2010; McNichols, 2010). See Figure 1 for a visual representation of internal and external factors influencing mentoring relations.

Due to its birth in economics, the exploitation of behavior for power and status will be forever associated with social exchange theory (Robbins, Chatterjee, \& Canda, 1998). According to Emerson, the dyadic relationship is defined by mutual dependence where one participant exerts power over the other and the other exercises a level of tolerance in response (Ritzer, 2010). The normative change effort is reinforced by the concept of fair exchange. In the bureaucratic context, the implied role of the mentor is best described as omnipotent. In order for the sharing of knowledge to be valued, a contemporary definition for mentoring must be centered on mutual engagement and empowerment. Thus, exchange values associated with social capital must be shaped by the environment. Unfortunately, a change in the environment does not guarantee a change in individual 
behavior. Social exchange principles are rooted in self-interest which reinforces the fact that federal grade levels (salaries) are linked to expertise. Until the question of what's-init-for-me can be answered with an altruistic tone, the mentoring exchange will be reduced to power and status.

Figure 1. Structural Change due to Internal and External Factors

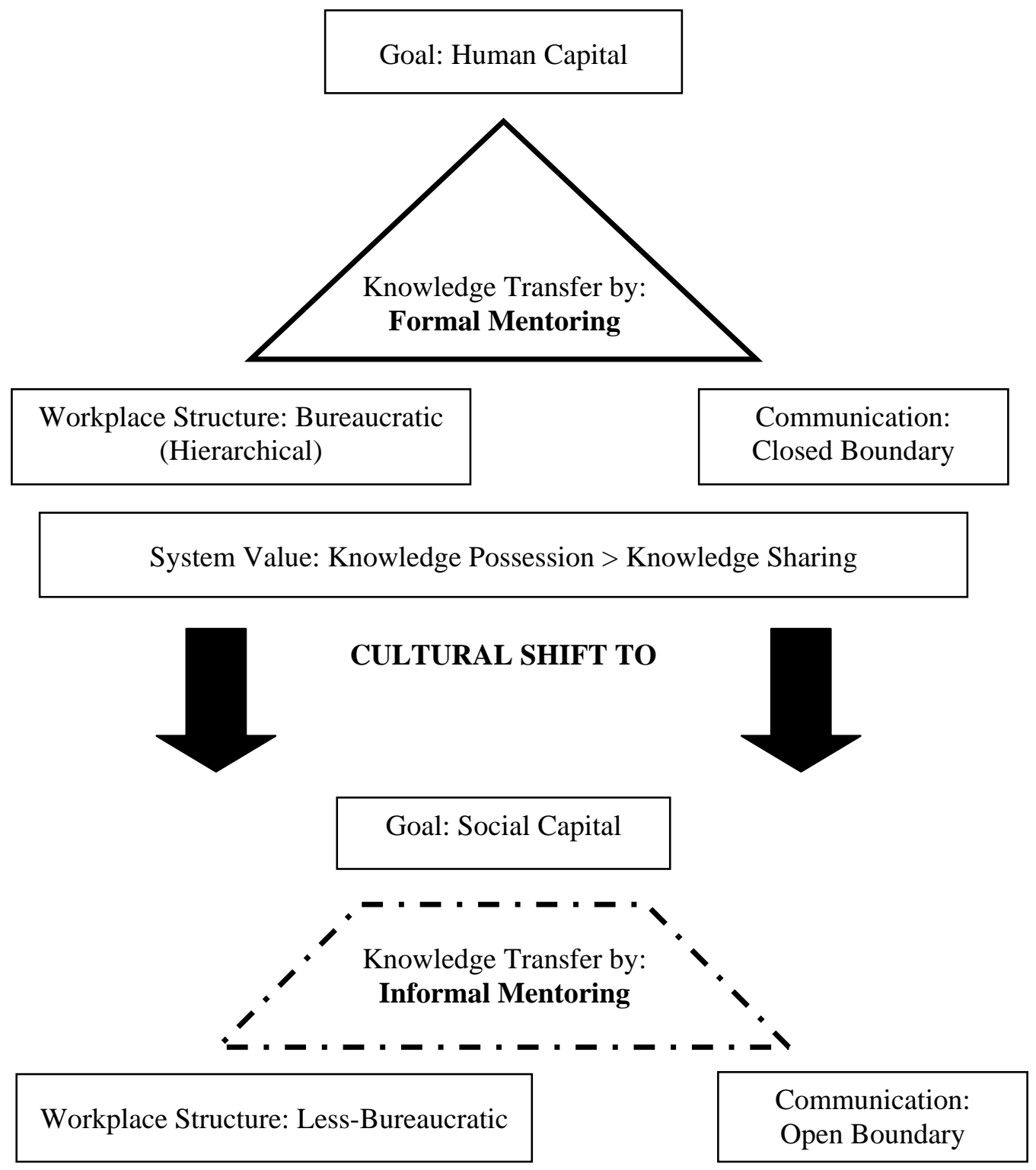

System Value: Knowledge Sharing > Knowledge Possession 


\section{Implications for Knowledge, Practice, and Further Development}

Due to the reliance on dynamic relationships, the author suggests that further examination to better identify a theoretical frame for grounding workplace mentoring relationships is required. While facilitating federal workplace mentoring programs is one potential example of a social work application, the aim of this paper was to introduce the reader to the concepts of mentoring and social exchange for utility across the profession. With that said, creating an organizational work climate that encourages and supports informal relationships between employees is paramount. Structurally, a paradigm shift from formal to informal mentoring will require a change in organizational culture and theoretical context. Simply, while federal employees gain technical knowledge, they should equally receive opportunities to develop or enhance interpersonal skills. Cultural context may be just as important as organizational structure. For instance, in the Chinese organizational context, mentoring supports the collectivist culture and Confucian value system. Regardless of the structure, mentoring is shaped by the cultural concept, "quanxi", defined by a societal interpersonal connection that supports mutual interests and benefits (Liu et al., 2009).

In the workplace, mentoring must be seen as the reflexive process by which colleagues enter into mutual engagements for continuous, experiential learning in support of achieving superior performance through the transfer of empowerment, knowledge, and perspective. From this point forward, to marginalize the effects of attrition, budgetary restraint, and retirement on federal agencies, organizational learning must be centered on routine transfer and sharing of tacit knowledge through informal relationships. In fact, the sharing of knowledge must be seen as a core value, embedded within in the workplace, and supported by the upper echelons of leadership. In place of human capital, social capital through open communication will support the natural development of informal mentoring relationships based on mutual respect, shared values, and trust (Swigonski, 1993). Mentoring relationships for knowledge transfer in the bureaucratic workplace may benefit from using a social work approach. Social work is in the business of facilitating and fostering meaningful relationships (Graybeal, 2007). As outlined in the National Association of Social Workers (NASW) Code of Ethics,

Social workers understand that relationships between and among people are an important vehicle for change. Social workers engage people as partners in the helping process. Social workers seek to strengthen relationships among people in a purposeful effort to promote, restore, maintain, and enhance the wellbeing of individuals, families, social groups, organizations, and communities. (2008)

As emerging factors influence the federal workplace, the need to develop culturallysound and supportive mentoring relationships for competency and skill development will be critical. The social work approach and resulting perspective can assist agency leaders in aligning organizational structure for knowledge transfer (Cnaan \& Ditcher, 2008) by inspiring innovation over context-bound learning (Gambrill, 2005) and growth to capacity beyond the restrictions of over-socialization (Weick, 1987) while honoring shared knowledge. 


\section{References}

Blau, P. M. (1955). The dynamics of bureaucracy: A study of interpersonal relations in two government agencies. Chicago, IL: The University of Chicago Press.

Blau, P. M., \& Meyer, M. W. (1971). Bureaucracy in modern society $\left(2^{\text {nd }}\right.$ ed.). New York, NY: Random House Inc.

Cnaan, R. A., \& Dichter, M. E. (2008). Thoughts on the use of knowledge in social work practice. Research on Social Work Practice, 18(4), 278-284.

Cohen, N. H. (1999). The manager's pocket guide to effective mentoring. Amherst, MA: HRD Press.

Colley, H. (2002). A 'rough guide' to the history of mentoring from a Marxist feminist perspective. Journal of Education for Teaching, 28(3), 247-263.

Combs, G. M. (2003). The duality of race and gender for managerial African American women: Implications of informal social networks on career advancement. Human Resource Development Review, 2(4), 385-405. doi: 10.1177/1534484303257949

Cook, K. S., \& Whitmeyer, J. M. (1992). Two approaches to social structure: Exchange theory and network analysis. Annual Review of Sociology, 18, 109-127. Retrieved from http://www.jstor.org/stable/2083448

Cropanzano, R., \& Mitchell, M. S. (2005). Social exchange theory: An interdisciplinary review. Journal of Management, 31(6), 874-900.

Cunningham, S. (1999). The nature of workplace mentoring relationships among faculty members in Christian higher education. Journal of Higher Education, 70(4), 441463.

Darwin, A. (2000). Critical reflections on mentoring in work settings. Adult Education Quarterly, 50(3), 197-212.

Davidson, J. (2010, November 5). Attrition is high among new workers at many government agencies. The Washington Post. Retrieved from http://www.washingtonpost.com

DeLong, D. W. (2004). Lost knowledge. New York, NY: Oxford University Press.

Donaldson, S. I., Ensher, E. A., \& Grant-Vallone, E. J. (2000). Longitudinal examination of mentoring relationships on organizational commitment and citizenship behavior. Journal of Career Development 26(4), 233-249.

Dutton, J. E., \& Heaphy, E. D. (2003). The power of high quality connections. In K.S. Cameron, J.E. Dutton, \& R.E. Quinn, (Eds.), Positive organizational scholarship: Foundations of a new discipline (pp. 263-278). San Francisco, CA: Berrett-Koehler Publishers Inc.

Ensher, E. A., Thomas, C., \& Murphy, S. E. (2001). Comparison of traditional, stepahead, and peer mentoring on protégés' support, satisfaction, and perceptions of 
career success: A social exchange perspective. Journal of Business and Psychology, 15(3), 419-437.

Farganis, J. (2011). Readings in social theory (6 ${ }^{\text {th }}$ ed.). New York, NY: McGraw-Hill.

Federal Supervisor Training Act of 2010, H.R. 5522, $111^{\text {th }}$ Cong. (2010).

Fiol, C. M., O’Connor, E. J., \& Aquinis, H. (2001). All for one and one for all? The development and transfer of power across organizational levels. The Academy of Management Review, 26(2), 224-242.

Fouché, C., \& Lunt, N. (2010). Nested mentoring relationships: Reflections on a practice project for mentoring research capacity amongst social work practitioners. Journal of Social Work, 10(4), 391-406.

Gambrill, E. (2005). Different views of knowledge and how to get it: Exploring your personal epistemology. In E. Gambrill (Ed.), Critical thinking in clinical practice: Improving the quality of judgments and decisions ( $2^{\text {nd }}$ ed., pp. 85-122). Hoboken, NJ: Wiley \& Sons.

Gillies, V., \& Edwards, R. (2006). A qualitative analysis of parenting and social capital: Comparing the work of Coleman and Bourdieu. Qualitative Sociology Review, 7(2), 42-60.

Godwin, M. (2009, March). Preparing the next generation of local government professionals: mentoring, diversity, and professional affiliation. (Unpublished manuscript). Paper presented at the Annual Meeting of the Western Political Science Association, Vancouver, British Columbia, Canada.

Graybeal, C. T. (2007). Evidence for the art of social work. Families in Society, 88(4), 513-523.

Heimann, B., \& Pittenger, K. S. (1996). The impact of formal mentorship on socialization and commitment of newcomers. Journal of Managerial Issues, 8(1), 108-117.

Higgins, M. C., \& Kram, K. E. (2001). Reconceptualizing mentoring at work: A developmental network perspective. The Academy of Management Review, 26(2), 264-288.

Homans, G. C. (1985). [Review of the book Crosscutting social circles: Testing a macrosocial theory of intergroup relations, by P. M. Blau \& J. E. Schwartz, New York, NY: Academic Press, 1984]. Theory and Society, 14(3), 395-399.

Howell, J. M., \& Hall-Merenda, K. E. (1999). The ties that bind: The impact of leadermember exchange, transformational, and transactional leadership, and distance on predicting follower performance. Journal of Applied Psychology, 84(5), 680-694.

Hughes, J. A., Sharrock, W. W., \& Martin, P. J. (2003) Understanding classical sociology $\left(2^{\text {nd }}\right.$ ed.). Thousand Oaks, CA: Sage Publications. 
Hurley, T. A., \& Green, C. W. (2005). Knowledge management and the nonprofit industry: A within and between approach. Journal of Knowledge Management Practice. Retrieved from http://www.tlainc.com/articl79.htm

Katz, E. (2013). African Americans still face obstacles in federal workplace, report finds. Government Executive,1-2.

Khosrovani, M., \& Ward, J. W. (2011). African Americans' perceptions of access to workplace opportunities: A survey of employees in Houston, Texas. Journal of Cultural Diversity, 18(4), 134-141.

Labianca, G., \& Brass, D. J. (2006). Exploring the social ledger: Negative relationships and negative asymmetry in social networks in organizations. The Academy of Management Review, 31(3), 596-614.

Lam, A., \& Lambermont-Ford, J. P. (2010). Knowledge sharing in organisational contexts: a motivation-based perspective. Journal of Knowledge Management, 14(1), 51. doi: 10.1108/13673271011015561

Lawler, E. J., \& Thye, S. R. (1999). Bringing emotions into social exchange theory. Annual Review of Sociology, 25, 217-244.

Levy, M., Hadar, I., Greenspan, S., \& Hadar, E. (2010). Uncovering cultural perspective and barriers during knowledge audit. Journal of Knowledge Management, 14(1), 114127. doi: $10.1108 / 13673271011015606$

Leuenberger, D. Z., \& Kluver, J. D. (2005/2006). Changing culture: Generational collision and creativity. Public Manager, 34(4), 16-21.

Liu, D., Liu, J., Kwan, H. K., \& Mao, Y. (2009). What can I gain as a mentor? The effect of mentoring on the job performance and social status of mentors in China. Journal of Occupational and Organizational Psychology, 82, 871-895.

Lovett, F. (2006). Rational choice theory and explanation. Rationality and Society, 18(2), 237-272. doi: 10.1177/1043463106060155

Martinez-Brawley, E., \& Zorita, P. (2007). Tacit and codified knowledge in social work: A critique of standardization in education and practice. Families in Society, 88(4), 534-542.

Mason, M. K. (2010, September 29). Re: Debate over coaching and mentoring in today's workplace [Web log comment]. Retrieved from http://www.moyak.com/papers/coaching-mentoring-definitions.html

Matson, E., \& Prusak, L. (2010, September). Boosting the productivity of knowledge workers. McKinsey Quarterly, Retrieved from http://www.mckinseyquarterly.com/article_print.aspx

McNichols, D. (2010). Optimal knowledge transfer methods: A generation X perspective. Journal of Knowledge Management, 14(1), 24-37. doi: 10.1108/13673271011015543 
National Association of Social Workers (NASW). (2008). Code of Ethics. Retrieved from http://www.naswdc.org/pubs/code/default.asp

O’Neill, R. M., \& Blake-Beard, S. D. (2002). Gender barriers to the female mentor male protégé relationship. Journal of Business Ethics, 37, 51-63.

Payne, S. C., \& Huffman, A. H. (2005). A longitudinal examination of the influence of mentoring on organizational commitment and turnover. The Academy of Management, 48(1), 158-168.

Philipson, G. (2006, November 14). Newsman learns by the 70:20:10 rule. The Sydney Morning Herald, Retrieved from http://www.smh.com.au/news/perspectives/newsman-learns-by-the-702010rule/2006/11/13/1163266481828.html

Raabe, B., \& Beehr, T. A. (2003). Formal mentoring versus supervisor and coworker relationships: Differences in perceptions and impact. Journal of Organizational Behavior, 24, 271-293. doi: 10.1002/job.193

Rambo, E. H. (1999). Symbolic interests and meaningful purposes: Conceiving rational choice as cultural theory. Rationality and Society, 11(3), 317-342. doi: $10.1177 / 104346399011003003$

Reeves, T. Z. (2010). Mentoring programs in succession planning. State and Local Government Review, 42, 61-66. doi:10.1177/0160323X10368036

Ritzer, G. (2010). Contemporary social theory and its classical roots: The basics $\left(3^{\text {rd }}\right.$ ed.). New York, NY: McGraw Hill.

Robbins, S., Chatterjee, P., \& Canda, E. (1998). Behaviorism, social learning, and exchange theory. In S. Robbins, P. Chatterjee, \& E. Canda, (Eds.), Contemporary human behavior: A critical perspective for social work (pp. 349-385). Boston, MA: Allyn and Bacon.

Sandberg, S. (2013). Lean in: Women, work, and the will to lead. New York, NY: Knopf.

Scandura, T. A., \& Schriesheim, C. A. (1994). Leader-member exchange and supervisor career mentoring as complementary constructs in leadership research. The Academy of Management Journal, 37(6), 1588-1602.

Schroeder, R., \& Swedberg, R. (2002). Weberian perspectives on science, technology and the economy. British Journal of Sociology, 53(3), 383-401. doi:10.1080/ 000713122000000563

Shea, G. F. (2002). How to develop successful mentor behaviors ( $3^{\text {rd }}$ ed.). Landham, MD: National Book Network, Inc.

Sparrowe, R. T., \& Liden, R. C. (1997). Process and structure in leader-member exchange. The Academy of Management Review, 22(2), 522-552.

Swigonski, M. (1993). Feminist standpoint theory and the questions of social work research. Affilia, 8(2), 171-183. 
Talley, H. C. (2008). Mentoring: The courage to cultivate new leaders. American Association of Nurse Anesthetists Journal, 76(5), 331-334. Retrieved from http://www.aana.com/newsandjournal/Pages/October-2008-AANA-Journal-Table-ofContents.aspx

United States General Accounting Office (GAO), Subcommittee on Civil Service and Agency Organization, Committee on Government Reform, House of Representatives. (2001). Federal employee retirements: expected increase over the next 5 years illustrates need for workforce planning (GAO Publication No. 01-509). Retrieved from http://www.gao.gov/new.items/d01509.pdf

United States General Services Administration, Public Buildings Service. (2009). The new federal workplace: A report on the performance of six workplace $20 * 20$ projects. Retrieved from: http://www.gsa.gov/graphics/pbs/GSA_NEWWORKPLACE.pdf

United States Office of Personnel Management, Division of Strategic Human Resources Policy, Center for Workforce Information and Systems Requirements Workforce Information and Planning Group. (2008a). An analysis of federal employee retirement data: predicting future retirements and examining factors relevant to retiring from the federal service. Retrieved from http://www.opm.gov/feddata/RetirementPaperFinal_v4.pdf

United States Office of Personnel Management. (2008b). Best practices: Mentoring. Retrieved from http://www.opm.gov/policy-data-oversight/training-anddevelopment/career-development/bestpractices-mentoring.pdf

Wayne, S. J., Shore, L. M., \& Liden, R. C. (1997). Perceived organizational support and leader-member exchange: A social exchange perspective. The Academy of Management Journal, 40(1), 82-111.

Weick, A. (1987). Reconceptualizing the philosophical perspective of social work. The Social Service Review, 61(2), 218-230.

Yair, G. (2007). Existential uncertainty and the will to conform: The expressive basis of Coleman's rational choice paradigm. Sociology, 41(4), 681-698. doi: $10.1177 / 0038038507078923$

Zachary, L. J. (2000). The mentor's guide: Facilitating effective learning relationships. San Francisco, CA: Jossey-Bass, Inc.

Author note:

Address correspondence to: Chad Majiros, National Catholic School of Social Service, The Catholic University of America, 620 Michigan Avenue NE, Washington, DC 20064. Email: 97majiros@cardinalmail.cua.edu 